Accelerated Learning, Oleh: Khoiriyah

\title{
ACCELERATED LEARNING DAN PENERAPANNYA DI PERGURUAN TINGGI
}

\author{
Khoiriyah $^{*}$
}

\begin{abstract}
Abstrak
Tulisan berikut mencoba menyuguhkan tema program percepatan atau yang sering disebut dengan accelerated learning. Tujuan accelerated learning adalah menggugah sepenuhnya kemampuan belajar para siswa/pelajar, membuat belajar menyenangkan dan memuaskan bagi mereka, dan memberikan sumbangan sepenuhnya pada kebahagiaan, kecerdasan, kompetensi, dan keberhasilan mereka sebagai manusia.

Dalam sejarahnya, accelerated learning merupakan cara belajar alamiah, sebagai suatu gerakan modern yang mendobrak cara belajar di dalam pendidikan dan pelatihan terstruktur dalam kebudayaan Barat. Dalam penelitian otak modern, accelerated learning menemukan kiasan-kiasan tentang cara otak belajar dan berusaha merancang lingkungan belajar efektif "berdasarkan otak".
\end{abstract}

Kata kunci: Accelerated Learning, Program Percepatan

\section{Pendahuluan}

Selama ini, strategi penyelenggaraan pendidikan bersifat klasikal-massal, memberikan perlakuan yang standar (rata-rata) kepada semua mahasiswa, padahal setiap mahasiswa memiliki kebutuhan yang berbeda. ${ }^{1}$ Sudah barang tentu hal ini akan berdampak pada mahasiswa yang memiliki kemampuan dan kecerdasan di bawah rata-rata, karena memiliki kecepatan belajar di bawah kecepatan belajar mahasiswa lainnya, akan selalu tertinggal dalam mengikuti kegiatan belajarmengajar; sebaliknya, mahasiswa yang memiliki kemampuan dan kecerdasan di atas rata-rata, karena memiliki kecepatan belajar di atas

\footnotetext{
* Dosen Tetap STAIN Surakarta

${ }^{1}$ Ahmad Ali Riyadi, Politik Pendidikan: Menggugat Birokrasi Pendidikan Nasional, (Yogyakarta: Ar-ruzz Media, 2006), h. 45
}

Vol. 22 Nomor. 1 Januari 2011 
kecepatan belajar mahasiswa lainnya, akan merasa jenuh, sehingga sering berprestasi di bawah potensinya (under achiever).

Agar mahasiswa yang memiliki kemampuan dan kecerdasan luar biasa dapat berprestasi sesuai dengan potensinya, diperlukan pelayanan pendidikan yang berdiferensiasi, yaitu pemberian pengalaman pendidikan yang disesuaikan dengan kemampuan dan kecerdasan mahasiswa; dengan menggunakan kurikulum yang berdiversifikasi, yaitu kurikulum standar yang diimprovisasi alokasi waktunya sesuai dengan kecepatan belajar dan motivasi belajar mahasiswa.

Pelayanan pendidikan yang berdiferensiasi dengan menggunakan kurikulum yang berdiversifikasi dapat diimplementasikan melalui penyelenggaraan sistem akselerasi (percepatan kelas). Dengan sistem percepatan kelas (akselerasi), mahasiswa yang memiliki kemampuan dan kecerdasan luar biasa diberi peluang untuk secepatnya dapat menyelesaikan studi di Perguruan Tinggi, khususnya STAIN, kurang dari empat tahun. Mahasiswa dapat menyelesaikannya dalam kurun waktu enam semester atau kurang tanpa harus mengurangi jumlah mata kuliah yang ada dalam jumlah sistem kredit semester.

Penyelenggaraan sistem percepatan kelas (akselerasi) bagi mahasiswa yang memiliki kemampuan dan kecerdasan luar biasa merupakan salah satu strategi alternatif yang relevan; di samping bertujuan untuk memberikan pelayanan pendidikan sesuai dengan potensi mahasiswa, juga bertujuan untuk mengimbangi kekurangan yang terdapat pada strategi klasikal-massal.

\section{Kelas Percepatan (Akselerasi): Perspektif Teori}

Kelas Akselerasi atau lebih dikenal dengan Accelerated Learning adalah cara belajar yang alamiah, akarnya telah tertanam sejak zaman kuno. Sistem ini muncul yang mendobrak cara belajar di dalam pendidikan dan pelatihan terstruktur dalam kebudayaan Barat sebagai akibat adanya sejumlah pengaruh para pertengahan abad ke-20. ${ }^{2}$ Tepatnya di tahun 1970-an, Lynn Schroeder dan sheila Ostrander menerbitkan sebuah buku berjudul Superlearning yang mengemukakan karya psikiater Bulgaria, Georgi Lozanov. Buku itu mengundang perhatian banyak pendidik dan guru yang sedang mencari pendekatan nbelajar yang lebih efektif.

${ }^{2}$ Dave Meier, The Accelerated Learning Hanbook: Panduan Kreatif dan Efektif Merancang Program Pendidikan dan Pelatihan, penerj. Rahmani Astuti, (Bandung: Kaifa, 2004), h. 49 
Pada dasarnya accelerated learning adalah konsep yang menyajikan proses pembelajaran secara alamiah. Konsep pendidikan akselerasi adalah filosofi pembelajaran dan kehidupan yang mengupayakan demekanisasi dan memanusiakan kembali proses belajar, serta menjadikannya pengalaman bagi pribadi secara utuh. ${ }^{3}$ Dalam artian adanya proses transformasi pola pembelajaran dari pesoalan teori menuju persoalan riil.

Tujuan accelerated learning adalah menggugah sepenuhnya kemampuan belajar para pelajar, membuat belajar menyenangkan dan memuaskan bagi mereka, dan memberikan sumbangan sepenuhnya pada kebahagiaan, kecerdasan, kompetensi, dan keberhasilan mereka sebagai manusia. ${ }^{4}$

Dalam sejarahnya, accelerated learning merupakan cara belajar alamiah, sebagai suatu gerakan modern yang mendobrak cara belajar di dalam pendidikan dan pelatihan terstruktur dalam kebudayaan Barat. Dalam penelitian otak modern, accelerated learning menemukan kiasan-kiasan tentang cara otak belajar dan berusaha merancang lingkungan belajar efektif "berdasarkan otak" yang menuruti penelitian tersebut.

Untuk mendapatkan manfaat optimal dari penggunaan accelerated learning, sangat penting untuk benar-benar memahami prinsip-prinsip yang melandasinya. Accelerated Learning tidak akan memberi manfaat kepada mereka yang memisahkan metode-metodenya dari pondasi ideologisnya, yang menganggap accelerated learning semata-mata sebagai teknik kreatif dengan mengabaikan prinsip-prinsip yang mendasari teknik tersebut. Prinsip-prinsip dasar tersebut antara lain: (!) belajar melibatkan seluruh pikiran dan tubuh, (2) belajar adalah berkreasi, bukan mengkonsumsi, (3) kerja sama membantu proses belajar, (4) pembelajaran berlangsung pada banyak tingkatan secara simultan, (5) belajar berasal dari mengerjakan pekerjaan itu sendiri dengan umpan balik, (6) emosi positif sangat membantu pembelajaran, dan (7) otak-citra menyerap informasi secara langsung dan otomatis. ${ }^{5}$ Banyak hal yang harus dipertimbangkan dalam penyelenggaraan akselerasi supaya dapat optimal, antara lain prasyarat yang harus dipenuhi; identifikasi peserta didik, setting kelas, efek pemberian label,

\footnotetext{
${ }^{3}$ Ibid., h. 38.

${ }^{4}$ Waras Kamdi, Kelas Akselerasi dan Diskriminasi Anak, Harian Kompas, senin, 09 Agustus 2004.

${ }^{5}$ Meier, The Accelerated.., h. 54.
}

Vol. 22 Nomor. 1 Januari 2011 
dan evaluasi yang konsisten terhadap berbagai hal yang berkaitan dengan pelaksanaannya. ${ }^{6}$

Dave Meier menggunakan pendekatan SAVI (Somatis, Auditori, Intelektual, dan Visual) untuk belajar. ${ }^{7}$ Pembelajaran tidak otomatis meningkat dengan menyuruh orang berdiri dan bergerak ke sana kemari. Akan tetapi, menggabungkan gerakan fisik dengan aktivitas intelektual dan penggunaan semua indra dapat berpengaruh besar dalam pembelajaran. Unsur-unsur tersebut adalah:

1. Somatis: belajar dengan bergerak dan berbuat.

2. Auditori: belajar dengan berbicara dan mendengar.

3. Visual: belajar dengan mengamati dan menggambarkan.

4. Intelektual: belajar dengan memecahkan masalah dan merenung.

Keempat cara belajar ini harus ada agar belajar berlangsung optimal. Karena unsur-unsur ini semuanya terpadu, belajar yang paling baik bisa berlangsung jika semuanya itu digunakan secara simultan.

Dalam accelerated learning, sebagaimana pembelajaran yang lain, mempunyai tahap-tahap pembelajaran, antara lain:

1. Persiapan (Preparation) menggugah timbulnya minat.

2. Penyampaian (Presentation), perjumpaan pertama dengan pengetahuan atau ketrampilan baru.

3. Pelatihan (Practice), integrasi pengetahuan atau ketrampilan baru.

4. Penampilan Hasil (Performance), penerapan dan ketrampilan baru pada situasi dunia-nyata. ${ }^{8}$

Jika keempat unsur itu semuanya ada dalam satu atau lain bentuk, pembelajaran yang sebenarnya akan berlangsung.

Accelerated learning juga menggunakan sarana dan teknik dalam pembelajarannya. ${ }^{9}$ Sarana dan teknik ini tentu saja berhubungan dengan metode dan strategi pembelajaran. Sarana pendidikan merupakan segala sesuatu yang digunakan untuk mencapai tujuan dalam pendidikan. Sedangkan metode diartikan sebagai cara mengajar untuk mencapai tujuan. Penggunaan metode dapat memperlancar proses pendidikan sehingga pendidikan tercapai secara efektif dan efisien. Proses pengajaran intinya adalah kegiatan belajar para siswa. Tinggi

\footnotetext{
${ }^{6}$ SW Widodo, Optimalisasi Akselerasi Pendidikan, Harian Suara Merdeka, Senin, 13 Februari 2006.

${ }^{7}$ Meier, The Accelerated.., h. 90.

${ }^{8}$ Ibid., h. 103

${ }^{9}$ Waras Kamdi, Kelas Akselerasi dan Diskriminasi Anak, Harian Kompas, senin, 09 Agustus 2004.
} 
rendahnya kadar kegiatan belajar banyak dipengaruhi oleh model mengajar yang digunakan oleh guru. ${ }^{10}$ Dengan kata lain, metode merupakan suatu sarana untuk menemukan, menguji, dan menyusun data, yang diperlukan bagi pengembangan suatu disiplin, maka usaha pengembangan metode itu sendiri merupakan syarat mutlak. ${ }^{11}$ Bentuk mengajar merupakan langkah sedangkan metode merupakan sarana atau alatnya namun keduanya tidak dapat dipisahkan bahkan merupakan satu kesatuan. ${ }^{12}$ Ada banyak metode dan strategi belajar yang digunakan dalam proses belajar mengajar, terutama dalam pendidikan akselerasi.

Yang terpenting bahwa dalam proses pembelajaran itu guru mengetahui dan mengenal potensi anak didiknya. ${ }^{13}$ Guru dalam proses belajar mengajar memiliki fungsi yang sangat strategis dalam melaksanakan tugas mendidik dan mengajar, karena melalui proses pendidikan akan terbentuklah sikap dan perilaku peserta didik. ${ }^{14}$ Guru yang mengajar pada program akselerasi belajar adalah guru yang telah mengikuti seleksi dan mempunyai kualifikasi. Dukungan institusional dan profesional sangat menunjang perkembangan keefektifan guru. ${ }^{15}$

Rancangan yang digunakan dalam pendekatan akselerasi adalah Rancangan Instruksi Cepat (RIC). Tekanannya adalah mendapatkan hasil lebih baik, secara lebih cepat. Proses rancangan cepat ini prinsipprinsip, antara lain: (1) merancang dengan siklus belajar 4 tahap, (2) sesuai dengan semua gaya belajar, (3) membuat rancangan berdasar aktivitas, (4) menciptakan komunitas belajar, (5) bergantian menerapkan aktivitas belajar fisik-aktif dan aktivitas belajar fisik-pasif, (6) mengikuti aturan 30/70, dan (7) menciptakan rancangan yang luwes dan bertujuan terbuka. ${ }^{16}$ Dengan mengikuti ketujuh prinsip yang

\footnotetext{
${ }^{10}$ Nana Sudjana, Cara Belajar Siswa Aktif dalam Proses Belajar Mengajar, (Bandung: CV. Sinar Baru, 1989), h. 73.

${ }^{11}$ Imam barnadib, Filsafat Pendidikan, Sistem dan Metode, (Yogyakarta: Penerbit Andi Offset, 1992), h. 58

${ }^{12}$ Agus Mirwan, Teori Mengajar, (Yogyakarta: Sumbangsih Offset, 1989), h. 17

${ }^{13}$ Malik Fadjar, Tidak ada itu Kelas Akselerasi, Harian Kompas, Sabtu, 24 Juli 2004

${ }^{14}$ Chabib Thoha dan Abdul Mu'ti, PBM-PAI di Sekolah, Eksistensi dan Proses Belajar-Mengajar Pendidikan Agama Islam, (Yogyakarta: Pustaka Pelajar Offset, 1998), h. 177

${ }^{15}$ Suyanto dan Djihad Hisyam, Refleksi dan Reformasi Pendidikan di Indonesia Memasuki Millenium III, (Yogyakarta: Adicita Karya Nusa, 2000), h. 27

${ }^{16}$ Meier, The Accelerated.., h. 277.
} 
Accelerated Learning, Oleh: Khoiriyah

sederhana dan alamiah ini, akan dapat mempercepat perancangan sambil mengembangkan program pembelajaran yang lebih efektif. Accelerated learning lebih dari sekedar sekumpulan gagasan dan teknik pembelajaran yang kreatif. Accelerated learning adalah filosofi dan pendekatan yang menyeluruh dan terpadu pada pembelajaran, yang berlawanan dengan sebagian besar keyakinan dan praktik konvensional. Sifatnya sistematis, bukan kosmetis, dan menuntut untuk mengubah beberapa asumsi dasar mengenai pembalajaran jika ingin accelerated learning benar-benar berhasil. Yang terpenting dalam Accelerated Learning adalah keutuhan-keutuhan pengetahuan, keutuhan individu, keutuhan organisasi, dan keutuhan kehidupan itu sendiri.

Pada hakikatnya, ditinjau dari aspek kemampuan dan kecerdasan, mahasiswa dapat dikelompokkan kedalam tiga strata, yaitu: yang memiliki kemampuan dan kecerdasan di bawah rata-rata, rata-rata, dan di atas rata-rata. Mahasiswa yang berada di bawah rata-rata, memiliki kecepatan belajar di bawah kecepatan belajar mahasiswa-mahasiswa pada umumnya. Sedangkan mahasiswa yang berada di atas rata-rata, memiliki kecepatan belajar di atas kecepatan belajar siswa-siswa lainnya. Bagi siswa yang memiliki kemampuan dan kecerdasan rata-rata, selama ini diberikan pelayanan pendidikan dengan mengacu pada kurikulum yang berlaku secara nasional, karena memang kurikulum tersebut disusun terutama diperuntukkan bagi anakanak yang memiliki kemampuan dan kecerdasan rata-rata. Sementara itu, bagi siswa yang memiliki kemampuan dan kecerdasan di bawah rata-rata, karena memiliki kecepatan belajar di bawah siswa-siswa lainnya, diberikan pelayanan pendidikan berupa pengajaran remidi (remedial teaching), sehingga untuk menyelesaikan materi kurikulum membutuhkan waktu yang lebih panjang dari siswa-siswa lainnya. Sedangkan bagi siswa yang memiliki kemampuan dan kecerdasan di atas rata-rata, meskipun memiliki kecepatan belajar di atas kecepatan belajar siswa-siswa lainnya, belum mendapat pelayanan pendidikan sebagaimana mestinya. Bahkan, kebanyakan perguruan tinggi atau sekolah memberikan perlakuan yang standar (rata-rata), bersifat klasikal dan massal, terhadap semua siswa, baik siswa di bawah rata-rata, rata-rata, dan di atas ratarata, yang sebenarnya memiliki kebutuhan berbeda. Akibatnya, siswa yang di bawah rata-rata, akan selalu tertinggal dalam mengikuti kegiatan belajar-mengajar yang berlangsung; sebaliknya, siswa yang di 
atas rata-rata, akan merasa jenuh karena harus menyesuaikan diri dengan kecepatan belajar siswa-siswa lainnya. ${ }^{17}$

\section{Aspek Praktis Kelas Akselerasi}

Di Indonesia, munculnya program percepatan belajar atau lebih sering disebut kelas akselerasi mengingatkan para pemerhati lembaga pendidikan pada program sekolah unggulan. Dasar pemikirannya sama yaitu, peserta didik yang memiliki tingkat kecerdasan luar biasa berhak mendapatkan perhatian dan pelajaran lebih khusus agar dapat dipacu perkembangan prestasinya dan bakatnya.

Ada beberapa alasan logis yang masuk akal diselenggarakanya program ini. Pertama, alasan efisiensi sosial pragmatis penyelenggaraan pendidikan. Karena negara Indonesia demikian besar dengan penduduk amat banyak, dililit masalah pengembangan sumber daya manusia tetapi miskin dana untuk pendidikan, maka lebih baik mendayagunakan dana yang sedikit itu lebih secara signifikan untuk memacu anak-anak cerdas. Kedua, membuat kelas yang relatif homogen sehingga siswa yang merasa luar biasa atau cerdas tidak dirugikan oleh keterlambatan belajar siswa biasa. Sering dikeluhkan banyak dosen atau guru terhadap anakanak cerdas di kelas heterogen cenderung merasa cepat bosan belajar dan cenderung mengganggu. Karena itu anak-anak cerdas itu perlu mendapatkan layanan khusus di kelas terpisah dari kelas biasa. Dengan demikian, pengelolaan kelasnya lebih mudah. Ketiga, memberikan penghargaan (reward) dan perlindungan hak asasi untuk belajar lebih cepat sesuai dengan potensinya. ${ }^{18}$

Oleh karena itu, perlunya perhatian khusus kepada peserta didik yang memiliki kemampuan dan kecerdasan luar biasa untuk mengembangkan potensi peserta didik seoptimal mungkin. Penyelengaraan sistem percepatan kelas akselerasi bagi siswa yang memiliki kemampuan dan kecerdasan luar biasa merupakan salah satu strategi alternatif yang relefan, karena siswa yang memiliki kemampuan dan kecerdasan luar biasa memiliki kecepatan belajar dan motivasi belajar di atas kecepatan dan motivasi beljar siswa lainnya. Strategi alternatif itu di samping bertujuan untuk memberikan pelayanan

${ }^{17}$ Herry Widyastono,"Sistem Percepatan Kelas (Akselerasi) Bagi Siswa Yang Memiliki Kemampuan dan Kecerdasan Luar Biasa," dalam academe@indopubs.com, 27 Juny 2006.

${ }^{18}$ Waras Kamdi, Kelas Akselerasi dan Diskriminasi Anak, Harian Kompas, senin, 09 Agustus 2004.

Vol. 22 Nomor. 1 Januari 2011 
Accelerated Learning, Oleh: Khoiriyah

pendidikan sesuai dengan potensi siswa, juga bertujuan mengimbangi kekurangan yang terdapat dalam kelas.

Untuk itulah, diperlukan beberapa strategi yang terarah untuk pengembangan peserta didik. Strategi itu adalah: pertama, input siswa diseleksi secara ketat dengan menggunakan kriteria tertentu dan prosedur yang dapat dipertanggungjawabkan dan diukur. Kriteria yang digunakan adalah; prestasi belajar, standar deviasi di atas mean populasi siswa, emotional quotient berada di atas rata-rata populasi siswa, kesehatan dan kemantapan jasmani.

Kedua, kurikulum yang digunakan adalah kurikulum nasional yang standar, namun kemudian dilakukan improvisasi alokasi waktunya sesuai dengan tuntyutan belajar peserta didik yang memiliki kecepatan belajar serta motivasi belajar tingngi dibandingkan dengan kecepatan belajar dan motivasi belajar siswa lainnya. Dalam hal ini misalnya biasanya untuk menyelesaikan studi $\mathrm{S}-1$, yang biasanya memakan waktu 4 tahun, terdiri 8 smester, dipercepat menjadi 3, tahun pertama menjadi 3 semester, tahun ke dua menjadi 3 semester dan tahun ke tiga menjadi 2 semester.

Ketiga, tenaga pendidikan. Karena siswanya mempunyai kemampuan dan kecerdasan luar biasa, maka tenaga kependidikan yang menanganinya harus terdiri atas tenaga kependidikan yang unggul, baik dari segi penguasaan materinya, penguasaan metode pembelajarannya, maupun komitmen untuk melaksanakan tugas mengajar.

Keempat, diperlukan sarana dan prasarana yang menunjang yang disesuaikan dengan kemampuan dan kecerdasan siswa, sehingga dapat digunakan untuk memenuhi kebutuhan belajar serta menyalurkan kemampuan dan kecerdasannya, termasuk bakat dan minatnya, baik kegiatan kampus maupun luar kampus.

Kelima, diperlukan dana yang cukup. Untuk menunjang tercapainya tujuan yang telah ditetapkan perlu adanya dukungan dana yang memadai, termasuk perlunya disediakan dana intensif tambahan bagi tenaga kependidikan yang terlibat, berupa honor maupun fasilitas lainnya.

Keenam, perlunya pengelolaan atau manajemen yang baik dan transparan. Hal ini menyangkut dengan strategi dan implementasi seluruh sumber daya yangada dalam sistem perguruan tinggi untuk mencapai tujuan yang telah ditetapkan. Bentuk manajemen pada perguruan tinnggi dengan sistem kelas percepatan harus memiliki tingkat fleksibilitas yang tinggi, realistis dan berorientasi jauh ke depan. 
Accelerated Learning, Oleh: Khoiriyah

Pengelolaannya didasari oleh komitment, ketekunan, pemahaman yang sama, kebersamaan antara pihak yang terlibat dengan komponen ini.

Ketujuh, lingkungan belajar yang kondusif untuk berkembangnya potensi keunggulan menjadi keunggulan yang nyata, baik di lembaga pendidikan, masyarakat dan peserta didikanya.

Kedelapan, proses beajar mengajar yang bermutu dan hasilnya selalu dapat dipertanggungjawabkannya kepada siswa, lembaga maupun masyarakat.

\section{Beberapa Catatan Kritis}

Banyak hal yang harus dipertimbangkan dalam penyelenggaraan akselerasi supaya dapat optimal, antara lain prasyarat yang harus dapat terpenuhi, yaknii identifikasi peserta didik, setting kelas dan evaluasi yang kosisten terhadap berbagai hal yang berkaitan dengan pelaksanaannya.

Akan tetapi pelaksanaannya masih menimbulkan pertanyaan, haruskah mahasiswa yang dapat melakukan program pembelajaran hanyalah mahasiswa yang hanya mempunyai kecerdasan yang dianggap tinggi, bukankah hal ini dapat dikatagorikan sebagai bentuk diskriminasi dalam pembelajaran?

Hakekat pembelajaran percepatan kelas akselerasi pada hakekatnya sebuah strategi atau metode pembelajaran yang pada dasarnya mengakui setiap manusia memiliki cara belajar yang dapat mengantarkan dirinya menjadi yang terbaik. Ketika mahasiswa belajar tentang sesuatu sesuai dengan gaya belajarnya maka ia akan belajar dengan gaya natural. Karena belajar dengan cara ini sangatlah mudah, maka belajar lebih cepat berhasil. Oleh karenanya, prinsip pembelajaran percepatan berlaku unuk semua mahasiswa tanpa membedakan kategori apa pun, tidak hanya kategori mahasiswa apa pun. Pijakan utama percepatan belajar adalah karakteristik siswa. Misalkan mahasiswa mempunyai karakteristik kecerdasan untuk mengidentifikas mahasiswa. 
Accelerated Learning, Oleh: Khoiriyah

\section{DAFTAR PUSTAKA}

Barnadib, Imam, Filsafat Pendidikan, Sistem dan Metode, Yogyakarta: Penerbit Andi Offset, 1992.

Fadjar, Malik, Tidak ada itu Kelas Akselerasi, Harian Kompas, Sabtu, 24 Juli 2004.

Kamdi, Waras, Kelas Akselerasi dan Diskriminasi Anak, Harian Kompas, senin, 09 Agustus 2004.

Mirwan, Agus, Teori Mengajar, Yogyakarta: Sumbangsih Offset, 1989.

Meier, Dave, The Accelerated Learning Hanbook: Panduan Kreatif dan Efektif Merancang Program Pendidikan dan Pelatihan, penerj. Rahmani Astuti, Bandung: Kaifa, 2004.

Riyadi, Ahmad Ali, Politik Pendidikan: Menggugat Birokrasi Pendidikan Nasional, Yogyakarta: Ar-ruzz Media, 2006.

Sudjana, Nana, Cara Belajar Siswa Aktif dalam Proses Belajar Mengajar, Bandung: CV. Sinar Baru, 1989.

Suyanto dan Djihad Hisyam, Refleksi dan Reformasi Pendidikan di Indonesia Memasuki Millenium III, Yogyakarta: Adicita Karya Nusa, 2000.

Thoha Chabib, dan Abdul Mu'ti, PBM-PAI di Sekolah, Eksistensi dan Proses Belajar-Mengajar Pendidikan Agama Islam, Yogyakarta: Pustaka Pelajar Offset, 1998.

Widodo, SW, Optimalisasi Akselerasi Pendidikan, Harian Suara Merdeka, Senin, 13 Februari 2006.

Widyastono, Herry,"Sistem Percepatan Kelas (Akselerasi) Bagi Siswa Yang Memiliki Kemampuan dan Kecerdasan Luar Biasa," dalam academe@indopubs.com, 27 Juny 2006. 